\title{
studia
}

\section{Rzut oka na celne zasady nauki obyczajów od wieku Arystotelesa aż do Kanta przez Chrystiana Garwe}

Arystoteles, za najpierwszą zasadę moralności swojej założył twierdzenie: cnota $\mathrm{w}$ środku pomiędzy dwiema ostatecznościami zawsze jest umieszczona. Czy to twierdzenie jest prawdziwym? Czy w rzeczy samej służyć może za pierwszą zasadę w moralności całej? Oto pytanie, na które w tym miejscu odpowiedzieć zamierzam.

Najprzód więc: czy to prawda, że istota cnoty powinna być w rzeczy samej założoną na trzymaniu się środka pomiędzy dwiema niedoskonałymi ostatecznościami, z których jeden zależy na przesadzeniu, a drugi na zbyt małym stopniu owego popędu albo dążenia, który nas do jakowej sprawy unosi? To prawdzi się oczywiście o wszystkich powinnościach umiarkowania, które nauki obyczajów właściwej człowiekowi większą część zapewne stanowią, a przynajmniej za podstawę jej służą. Człowiek zupełnie panujący nad sobą samym i wszystkie zmyślne skłonności w przyzwoitym zawsze utrzymujący porządku mógłby zapewne bez wielu innych przepisów zawsze być $\mathrm{w}$ postępkach swoich roztropnym, zawsze sprawiedliwym, a w swoim 
czasie odważnym. Atoli czegoż właściwie potrzeba do panowania nad zmyślnymi żądzami: albo raczej, jakie jest prawidło porządku, podług którego należałoby granicę tymże rządzom zakreślić? Najprzód te wszystkie uniesienia pierwiastkowe od natury pochodzą, a ta na próżno zapewne nadała je człowiekowi. Wszystkie są dla niego nie mniej użyteczne, jak i potrzebne. Bez skłonności ku rozkoszy i bez żywego ku boleści wstrętu, bez miłości zmyślnej i bez zmyślnej odrazy, bez bojaźni niebezpieczeństwa i bez popędu ku utrzymaniu samego siebie, bez chęci odnoszących się tak do własnego, jako i innych ludzi dobra, nie mógłby prawie człowiek nazwać się żywą istotą, a cóż dopiero rozumną? Doskonałość człowieka tak w stosunku do charakteru jego, jako też w stosunku do każdej sprawy szczególnej konieczne wyciąga, aby te wszystkie skłonności nie tylko znajdowały się w człowieku, ale znajdowały się w pewnym stopniu i z pewną mocą działały. Jako nie może być zdrowym ciało tego zwierzęcia, które ani głodu, ani pragnienia w przyzwoitym czasie nie czuje, tak nawet zdrowa dusza tego człowieka, w którym skłonność ku rozkoszy wstręt ku boleści albo nie obudza się wcale, albo bardzo słabo obudza. I w zmyślnych przeto skłonnościach należy przypuścić występny niedostatek, czyli naganną słabość. Powtórzę atoli, z drugiej strony pokazuje doświadczenie, że cnota i szczęśliwość ludzka nie ma główniejszego nieprzyjaciela nad górującą skłonność do zmyślnych uciech nad zbyteczny wstręt ku temu wszystkiemu, co jest nieprzyjemnym i trudnym, chociażby to razem albo do uniknienia złego nierównie większego, albo do pozyskania dóbr znakomitszych było nieuchronnie potrzebnym, nad przesadzoną chciwość honoru lub dostatków, które w tysiącznych przypadkach nęci człowieka do krzywdzenia praw i należytości innych ludzi. Już samo zdrowie i życie ludzkie przez nic na większe wystawianym nie bywa niebezpieczeństwo jak przez zbytki w pokarmu i napoju, które stąd jedynie pochodzą, że człowiek nadto jest chciwym zmyślnej uciechy z używaniem onych połączonej i skłonność swoją ku nim nie zamyka w tych granicach, które natura sama kojeniu nieuchronnych potrzeb jego założyła. Atoli większą jeszcze przeszkodą umysłowi, tak w staraniu się o pomnożenie własnej swojej doskonałości, jako też powinności swoich wykonywaniu, jest $\mathrm{z}$ jednej strony, nieumiarkowana żądza uciech zmyślnych środków do używania onej pomagających tudzież tegoż samego używania zbytek, z drugiej zaś strony, przesadzony wstręt ku każdej trudności i przykrości, która ma być przedsięwziętą: tudzież niedostatek wytrwania w pracy albo stałości w niebezpieczeństwach. W wirze zmyślnych rozkoszy żaden człowiek nie może stać się roztropnym ani przenikłym i pełnym zdrowych myśli. A bardzo często bez nieustannej i uciążliwej pracy 
ani pożyteczne wiadomości nie mogą być nabytymi, ani władzę umysłu przez przyzwoite ćwiczenia rozwianemi. Żadnego człowieka poczciwość nie utrzyma się bez uszczerbku, jeżeli albo gorąca chciwość pieniędzy każe mu chwytać się wszystkich środków, które do pozyskania ich służą, albo przesadzona żądza honorów w każdym ze współubiegających się wystawia mu własnego nieprzyjaciela. Odwagi i męstwa ani spodziewać się nawet w tym umyśle nie można, w którym przywiązanie do uciech i wygody tudzież wstręt ku boleści ranom i śmierci nieograniczenie panują.

W popędach przeto i uczuciach zmyślnych znajduje się jeszcze druga występna i naganna ostateczność, to jest przesadzenie i zbytek. Cnota umiarkowania i panowania nad sobą nie może być przeto inaczej wykonywana tylko przez ostateczne utrzymywanie równowagi pomiędzy dwiema walczącymi z sobą, iż tak rzeknę, stronami: pomiędzy lenistwem i opieszałością w uczuciach i popędach zmyślnych, które robią człowieka mniej czynnym, które ciało jego czynią mniej sposobnym do usług duszy, zmyślność do usług rozumu i pomiędzy górującą tychże popędów i uczuć żywością, która rozum człowieka zaślepia i jego panowania znać nie chce. Zasada przez Arystotelesa podana ustanawia prawdę, której inni filozofowie, a mianowicie stoicy nie dostrzegli wcale, to jest: że cnota zupełnego wytępienia namiętności naszych nie wyciąga, że do prawdziwej doskonałości równie należy, abyśmy czułemi byli na ponęty zmysłów, postrzegali z łatwością piękność w kolorach i postaciach, melodię $\mathrm{w}$ tonach głosu, przyjemność $\mathrm{i}$ smaczność $\mathrm{w}$ pokarmach i tego wszystkiego pragnęli, jakże byśmy nie dopuścili nad sobą tym ponętom zmyślnym panować, że byśmy uciechy oka, ucha, smaku i całego ciała nie zakładali sobie za cel najwyższy, do którego by wszystkie usiłowania nasze nieokreślenie dążyły. Arystoteles uznaje, że także i mądry, to jest cnotliwy człowiek powinien czuć w sobie mimowolną żywą żądzę ku utrzymaniu życia ku pożądaniu i pomnażaniu dostatków ku potędze i dostojnością, którego wynoszą nad innych, a przeciwnie doświadczać mocnego wstrętu ku śmierci ku ubóstwu ku upodleniu i sprawiedliwie przeznacza tylko dla rozumu urząd położenia przyzwoitych granic tym wszystkim zmyślnym pragnieniom i kojeniu każdego czas, miejsce, trwanie i najstosowniejszą okoliczność wyznaczać. Te granice ani we wszystkich ludziach ani we wszystkich przypadkach zupełnie są równemi. Jeden człowiek może bez nagany używać zmyślnych uciech, od których drugi wstrzymywać się z obowiązku powinien aż zdrowym żołądkiem więcej nierównie jeść można niż kiedy ten jest słabym. Nadobnie okoliczności czasu osobistego położenia i szczególnej sprawy, którą nam wykonać wypada, mogą niekiedy dozwolić nam większego ulegania 
zmyślnym żądzom, a niekiedy ścisłe położyć im granice. Arystoteles przeto z niemałą trudnością szukał wyrazu, którym by najdobitniej moc i potęgę rozumu nad skłonnościami zmyślnemi oznaczyć można było. Wyraz środka zdawał mu się na to najdogodniejszym, bo w rzeczy samej we wszystkich ludziach i we wszystkich przypadkach wspólnym przymiotem umiarkowania jest ani nadto mało, ani nadto wiele nie czynić.

Użycie tego wyrazu uczyniło samą zasadę oczywiście fałszywą, ponieważ skazuje nad chwałę i zawsze równe zakreślenie, którego cnocie umiarkowania wcale nie masz, lecz przez to samo użycie stała się też zasada jaśniejszą. Ponieważ środek skazuje widocznie na chronienie się dwóch równie nagannych ostateczności, z których jedną jest nadto wiele, a drugą nadto mało. Nie zawsze w ścisłym i dokładnym środku pomiędzy zuchwalstwem i trwożliwością pomiędzy najwyższą jątrzliwością zmyślną nieczułością zupełną powinniśmy się znajdować. Arystoteles mówi to wyraźnie w ostatnim rozdziale księgi swojej. Nasza odwaga może niekiedy zbliżać się do zuchwalstwa, a umiarkowanie powinno czasem zamknąć się w granicach zupełnej wstrzemięźliwości. Atoli we wszystkich przypadkach będzie zawsze znajdować się granica, której przestąpienie byłoby szaleństwem i występkiem.

Atoli zapomniawszy nawet, iż zasada przez Arystotelesa podana wcale jest nieoznaczoną albo raczej, że w niepoliczonych przypadkach bardzo fałszywe oznaczenia cnocie umiarkowania nadaje, czyliż jednak umiarkowanie jest jedyną cnotą człowieka albo czy wszystkie cnoty można równie łatwo podciągnąć pod wyobrażenie równego oddalenia się od dwóch ostateczności, $\mathrm{z}$ których jeden na niedostatku, drugi na przesadzeniu zależy?

Czyliż nie znajdują się doskonałości, o których nabycie bez granic i miary starać się można? A w których zbytek mieć wcale miejsca nie może? Czyliż nie znajdują się usiłowania, których ciągnienie, gdyby można było aż do nieskończoności zachodzące nie tylko nie zasługiwałoby na naganę, ale najwyższego raczej warte było uwielbienia? W rzeczy samej znajdują się takie usiłowania. Nie ma żadnego powodu, dla którego byśmy w nabywaniu szlachetnych wiadomości powinni byli koniecznie umiarkowanie zachować. Jak nieograniczone pomnażanie i rozszerzanie nie jestże raczej celem i przeznaczeniem człowieka. Równie także nasza życzliwość i dobroć nie potrzebowałaby wcale żadnego określenia, gdyby sposoby i siły nasze nie ścieśniały same okręgu naszej czynności. Odwaga ile jest mocą duszy i charakteru, nie może 
nigdy być przesadzoną, a zuchwalstwo nie tylko nie jest zbytkiem tej mocy, ale raczej widocznie z słabości umysłu z zbliżającej się bardzo ku rozpaczy pochodzi.

Jeżeli niekiedy można słusznie upomnieć człowieka, ażeby nie był nadto mądrym i nadto sprawiedliwym, to upomnienie nie odnosi się wcale do wspomnianych przymiotów w zupełnej czystości i przyrodzonej doskonałości uważanych. W tym przypadku albo usiłuje moralista uniżyć fałszywą pychę i zniszczyć przywłaszczenia tych osób, które dla nabytych w pewnym stopniu wiadomości i zasług rozumieją się być nad cały naród ludzki wyższemi. Chce mówić do nich: nie wystawiajcie sobie żebyście już mieli dosięgnąć najwyższego stopnia mądrości dobroci. Albo jeżeli mówi o samych tych przymiotach, chce tylko wtenczas oznaczyć, że ponieważ czas i siły człowieka są bardzo ścieśnionemi, tyle tylko $\mathrm{z}$ obydwu na pozyskanie wspomnianych przymiotów łożyć powinien, ile im się słusznie należy w stosunku do innych celów, ku którym razem dążyć równie [jest] obowiązany. Chociaż człowiek nigdy mieć dosyć wiadomości nie może, ile atoli czyni, jeżeli swoją naukę kosztem zdrowia swego rozszerza. Chociaż być nigdy nadto życzliwym i dobrym nie może, może atoli źle czynić, jeśli hojnością swoją wtrąca w ubóstwo samego siebie.

Wszystkie dążenia do prawdziwej i absolutnej doskonałości miernemi być i w oznaczonym środku zamkniętymi nie mogą, a stąd przez tenże środek i przez tę mierność wytłumaczyć ich niepodobna. Oprócz tego znajduje się jeszcze cnota na samych tylko opuszczeniach należąca, a taką jest sprawiedliwość, do której zasada przez Arystotelesa podana nie może być przyzwoicie zastosowana. Nie krzywdzić nikogo i nie nadwerężać cudzej należytości, jest czynić pojedynczym i absolutnym, co nie tylko nie unosi się w środku pomiędzy dwiema ostatecznościami, ale co nawet podobnych ostateczności mieć żadną miarą nie można. W ścisłej sprawiedliwości ani o niedostatku, ani o przesadzeniu pomyśleć nawet nie można. Sam nawet Arystoteles potrzebował nieco całej bystrości swojej, potrzebował sofizmatów i przekształcania dawnych wyrazów na zupełnie nowe znaczenie, ażeby cnotę sprawiedliwości wystawił jako środek pomiędzy dwiema ostatecznościami. Stąd żadna część dzieła jego nie jest ani ciemniejszą, ani też bardziej powikłaną nad tę, która o sprawiedliwości traktuje. Zasada przeto Arystotelesowa jest już z tego względu niedostateczną, ponieważ nie obejmuje moralności całej. 
3.

Tymczasem w cnocie nawet umiarkowania, do której najcelniej może być zastosowana, jestże atoli rzetelna i prawdziwa zasada, istotnym przymiotem natury ludzkiej, z którego niby ze źródła wszystkie człowieka wypływałyby powinności, albo czy nie jest raczej punktem, z którego wszystkie pod pewnym przynajmniej względem uważanemi być mogą? W rzeczy samej do istoty cnoty nie należy koniecznie, aby ta pomiędzy dwiema znajdowała się ostatecznościami. Doskonałość nie zależy zapewne na samym ograniczeniu. Ale ponieważ natura ludzka jest ze wszech względów ograniczona i z tej przyczyny zaszczytem jest oraz powinnością rozumu poznać dokładnie te granice i mieć na nie baczność w tych ustawach, które wolnym sprawom naszym przepisuje. Istota umiarkowania, ile moralnej cnoty należy na zgodności i odpowiadaniu żądzy naszych następującym trzema rzeczom, najprzód naturze człowieka, ile ten jest działającą istnością, po wtóre z celami, które przez sprawy nasze usiłujemy osiągnąć, na koniec z okolicznościami, które sprawom naszym towarzyszą i do osiągnięcia tych celów pomagają.

W pierwszym względzie jest ona przyzwoitym poznaniem samego siebie, a moralna jej cena zależy na uważaniu samego siebie, które do tego poznania jest nieuchronnie potrzebnym i oraz na mocy umysłu do dawania oporu wszystkim nieprawym uniesieniom wystarczającej. W drugim względzie jest stosownością zachodzącą pomiędzy wyobrażeniami tak dzielności od nas użytej jako celu zamierzonego; i oraz obejrzeniem całej w ogóle doskonałości naszej, tudzież przyzwoitym odważeniem jednego dobra względem drugiego.

Najprzód: ten, który szuka celu ograniczonego, czyli bezrozumnie kiedy więcej czasu, siły, i w ogóle więcej natężenia używa niźli rzecz cała potrzebuje. Kto zamierza pokarmu i napoju dla zasilenia swego ciała używać, bardzo źle czyni kiedy przy stole granicę łaknienia i pragnienia przechodzi. Kto w nabywaniu i pomnażaniu dostatków upatruje kojenie potrzeb życia i opatrzenie wygód pożyciu towarzyskiemu przyzwoitych, ten bardzo źle czyni, który chciwość swoją posuwa aż do zbierania wielkich bogactw, które szczególnie do zbytku i miękkości prowadzą.

Po wtóre: ten, którego natura biernym ulega potrzebom, a który pracę swoją pomiędzy wiele dóbr do szczęśliwości jego nieuchronnie potrzebnych dzielić powinien, bardzo czyni nieprzyzwoicie, kiedy ku jednemu z tychże dóbr wszystkie swoje żądze obraca i całą dzielność swoją otrzymaniu jego poświęca. Człowiek ma ciało, które opatrywać powinien, zmysły, którym obowiązany przystojnych uciech dostarczyć. Ale ma także umysł, który po- 
trzebnemi wiadomościami karmić ma i wzbogacać należy; ma naturę moralną, która jedynie przez porządek i harmonię tak między wewnętrznemi poruszeniami, jako i zewnętrzną czynnością zachodzące może być ukojoną. Jest na koniec członkiem społeczeństwa ludzkiego, którego nieuchronnie do szczęśliwości swojej potrzebuje, lecz które nie inaczej ofiaruje mu stosowne do tego posługi, jak kiedy że wzajemnie przez własne posługi zapłaci. I w społeczności także ludzkiej powinien on część jedną swojej uwagi, swojej skłonności i swego rozumu poświęcić.

Kto więc zapomniawszy na wszystkie inne cele, wszystkie dni życia swego zmyślnej rozkoszy poświęca, kto zaniedbawszy kształcenie i oświecenie swego rozumu i zostawiwszy serce zupełnej nieczułości moralnej, puszcza się jedynie na zbieranie bogactw przez lichwę lub bezsumiennie usiłuje przyprowadzać do skutku widoki nieograniczonej ambicji, ten gardzi wszystkiemi celami, jeden szczególnie wyjąwszy i chybi tym samym najwyższego celu swojego to jest prawdziwej szczęśliwości, która na połączeniu tych wszystkich celów zawisła. Czyni to człowiek nieumiarkowany i z tej przyczyny zbrodnię moralną popełnia.

Drugi wzgląd, w którym umiarkowanie jest cnotą, albo raczej druga przyczyna dla czego zachowanie jego liczy się między powinnościami człowieka, zależy na ograniczeniu albo szczególniejszym zakreśleniu okoliczności, w których działa, środków, których zdoła używać osób, które czynności jego dopomagają. Zaiste sprawy człowieka nie sięgają dobra całego rodu ludzkiego, a tym bardziej dobra całego świata, wyznaczono mu zajmować się małą cząstką wspólnego całemu narodowi ludzkiemu zatrudnienia, to jest pomnażaniem doskonałości powszechnej. Niech on będzie wodzem, niech będzie ministrem, niech będzie nawet monarchą, zawsze jest atoli pojedynczym kołem wielkiej machiny, której nieprzerwane poruszenie zbliża świat do najwyższego celu swojego. Obowiązany przeto tak ograniczyć własne cele, aby nie przeszkadzały równie użytecznym celom, ku którym dążą inni ludzie; obowiązany żywość swej chęci unoszącej go do swego celu tak miarkować, ażeby przez nie usiłowania drugich nie stawały się daremnymi. Równie jak ograniczonymi są jego cele, tak ograniczonymi są także i sposoby. Nie może żadnego przedsięwzięcia zaczynać, do którego dokonania zbywa mu na pomocy i środkach. Krótko mówiąc, powinien żądze swoje równie do własnych okoliczności jako i do osoby stosować. Umiarkowanie jest powinnością dla niego, ponieważ niemniej siły ciała i umysłu jego, jako też i wyznaczonym okręg działania są we wszystkich względach ograniczonymi. 
Zasada więc od Arystotelesa podana nie tylko przez to grzeszy, że nie wyznacza przyczyny na naturze człowieka i na jego położeniu opartej, ale jest raczej prawidłem $z$ niej dopiero przez dalekie wyciągnionym wnioski, prawidłem niczem nie dowiedzionym i niemal zupełnie samowolnym.

Jeżeli rzecz tę całą jeszcze lepiej zgłębiamy, postrzegamy łatwo, że umiarkowanie albo raczej obowiązek trzymania się środka pomiędzy dwiema ostatecznościami, z których jedna jest zbytkiem, a druga niedostatkiem, ściąga się najcelniej do ciała człowieka i że duch jego w tym wszystkim sam w sobie działać może, żadnemu nie ulega ścieśnieniu i że dążenie i czynność swoją do nieskończoności może posunąć. Przez umiarkowanie ograniczają się tylko albo zmyślne uciechy, które w granicach tylko przyzwoitych użyte przynoszą rozkosz prawdziwą, kiedy zaś za nie wystąpią, w rzetelną zmieniają się boleść, a niszcząc ciało, osłabiają razem i umysł; albo też używanie rzeczy do utrzymania życia służących, które ponieważ ciało jest co do miejsca ograniczonym i pewną tylko ilość materii i ruchu do zachowania siebie potrzebuje, z tych wszystkich względów powinno być koniecznie do pewnych granic ścieśnionym. Jeżeli umiarkowanie chciwość pieniędzy i honoru w pewnych granicach zamyka, pochodzi to jedynie stąd, że te pomagają wiele do wolnego używania zmyślnych uciech, a za tym jako środki stosownie do wartości zamierzonego celu być ograniczonymi powinny. Na koniec we wszystkich sprawach, do których ciało jako narzędzie koniecznie jest potrzebnym, należy także i dzielność duszy do tego stopnia miarkować, ażeby między nią a siłami ciała zupełna zachodziła harmonia. Jeżeli obowiązani jesteśmy nasze chęci, nasze zamiary stosownie do naszego $\mathrm{w}$ obywatelstwie położenia stosownie do dostatków, do powagi i do związków z innymi ludźmi układać: pochodzi to stąd, iż przedsięwzięcia nasze odnoszące się do widocznego świata samą dzielnością umysłu nie mogą być wykonaniem, lecz potrzebują koniecznie pomocy ciała, które dla ograniczenia sił swoich obyć się bez współdziałania innych ludzi nie może, to zaś jedynie pozyskuje się albo przez sławę, albo przez honory, albo przez dostatki.

Przeciwnie w tym wszystkim, co się odnosi jedynie do umysłu naszego, gdzie on szczególnie sam działa i gdzie rzecz tylko o samą idzie doskonałość, jego tam żadnych natura nie położyła nam granic, tam żadnych także granic usiłowaniom naszym nie wyznacza rozum. Umysł ludzki zdatny jest do nieustannego pomnażania doskonałości swojej, do rozszerzania okręgu swojej dzielności, które jedynie z śmiercią naszą ustaje albo przynajmniej naszemu chowa się oku. Ciało w wielkości, mocy i piękności swojej do pewnego tylko rośnie i pomnaża się czasu po upłynnieniu, którego w tych wszystkich 
względach coraz się zmniejsza i zbliża ku zupełnemu zmniejszeniu. Jeżeli ten wzrost i pomnażanie się umysłu naszego żadnego w rzeczy samej nie ma kresu, nie zapewni nas o tym doświadczenie, ale toż doświadczenie nie pokazuje nam także granic jego, ponieważ odtąd wiedziemy zawsze naród ludzki w postępie i wzroście nieustannym. Różnica zachodząca w tym względzie pomiędzy ciałem a duchem jest zaiste niezaprzeczona a stąd musi także zachodzić różnica pomiędzy sprawami, które sam tylko duch wykonywa, a pomiędzy temi, do których wpływa koniecznie ciało. W uniesieniach ku prawdzie, ku znajomościom i ku moralnej doskonałości tudzież w rozkoszy, której z poznania rzeczy i z cnoty swojej doświadcza umysł nasz, żadnych granic stanowić sobie nie może; przeciwnie we wszystkich popędach, w których albo ciało koniecznie działa na umysł jako np. w namiętnościach, albo w których umysł pomocy i wpływu ciała używa, jako np. w staraniu się o zewnętrzne dobra, musi koniecznie umysł stosować dzielność swoją do materii albo też opierać się onej; musi miarkować owe poruszenia, których ciału jego nerwom i muskułom udziela dla oszczędzania ich siły i niezniszczenia owych zupełnego.

Ludzkie potrzeby i prace, do których wpływa ciało, niemal są niepoliczone: owe zaś które sam tylko umysł zajmuje nierównie co do liczby szczuplejsze ważnością i natężeniem swoim, tamte przenoszą i nad niemi, iż tak rzekę, panują. Te zdają się być następujące.

Umysł, czyli istota myśląca i chcąca rozumnie, żąda równie jak każda rzecz czująca bytność swoją trwałego ciągu tejże bytności. Pragnie na wieki myśleć i działać. Po wtóre, umysł dąży tak chęcią i usiłowaniem ku uszczęśliwieniu swojemu, to jest ku stanowi, w którym by miał upodobanie i w którym by zawsze pragnął zostawać. Jaśniejsze i dokładniejsze tego wszystkiego wytłumaczenie jest niepodobnym równie jak niepodobnym jest dalsze wytłumaczenie czucia samego siebie, z którym ta żądza niezłożoną jedność stanowi. Kto nie zna, co to jest czuć samego siebie i co jest być szczęśliwym, temu nie pokaże tego żadna filozofia, ponieważ nie jest człowiekiem, ani nawet żywą istotą. A kto każdy stan upodobania miesza zmyślną uciechą, tego niepodobna o czem innym przekonać, ponieważ albo nie jest duchem, albo przesądnemu swemu mniemaniu poświęca wyroki duchownej swojej natury. Ta żądza uszczęśliwienia rozciąga się także bez granic tak co do trwania, jako i stopnia swojego; ponieważ duch równie umie liczyć chwile swojej bytności, jak stopnie przyjemnego bytu odważać, a zawsze bytność najdłuższą i najwyższy stopień przyjemności przynosi. Uszczęśliwienie jest trwałym i coraz wzrastającym upodobaniem w samym sobie pomysł niewytłumaczony, lecz dla każdego jasny i w każdym się znajdujący. Atoli ten stan upodobania z dwóch 
znowu składa się części i dwa pierwiastkowe popędy ma sobie właściwymi. Chociaż albowiem duch i jego dzielność żadnych nieprzypuszczają części rozróżniamy w nim jednak dwie odmienne władze: władzę poznawania i władzę chcenia. Doskonałość władzy poznawania, czyli upodobanie i przyjemność ducha, ile ten jest myślącą istotą, zależy na mnóstwie i na prawdziwości wyobrażeń. Stąd rodzi się pierwszy duchowny, czyli umysłowy popęd umiętności i prawdzie. Doskonałość woli, czyli stan upodobania ducha, ile wewnętrznie ku czemu dążącego albo do usiłującego wykonać co zewnętrznie przez ciało zależy na obyczajności wyobrażeniu równie jasnym każdemu, lecz wcale niewytłumaczonym, w stanie umysłu, który ze zdrowiem ciała bardzo wielkie ma podobieństwo, a którego dzielność z poruszeniami zdrowego ciała słusznie porównaną być może. Stąd wynika drugi popęd czysto duchowny, czyli umysłowy popęd ku doskonałości moralnej. Dążeniu tych obydwóch popędów żadne prawa nieścieśnianą granice. Możemy się bez granic w wiadomościach naszych pomnażać, możemy coraz więcej o ich prawdziwości zapewniać, czujemy się ku temu uniesionymi i czynimy dobrze, kiedy za tym uniesieniem idziemy. Możemy zawsze mądrymi i lepszymi się stawać. Pragnienie tego znajduje się nawet w sercu zbrodniarza, a bardzo dobrze czynimy, kiedy dążeniu ku cnocie żadnych nie zakładamy granic. Za różność zachodzącą pomiędzy uniesieniami czysto umysłowymi, a pomiędzy temi, na które ciało, czyli jako przyczyna, czyli jako narzędzie wpływać musi, nie została przyzwoicie poznaną, a przez to nieograniczoność pierwszych, a konieczne ścieśnienie drugich niedostrzeżonych, stąd zaś umiarkowanie w żądzach za jedyną człowieka cnotę od Arystotelesa i innych założoną została, poszło to stąd iż o duchowną nawet doskonałość bez pomocy i wpływu ciała człowiek starać się nie może. Dla pomnożenia wiadomości naszych musimy koniecznie zmysłów do uważania zewnętrznego świata używać, musimy nasze myśli tonami głosu wyrażać. Udzielać ich tym sposobem innym ludziom i od nich tąże drogą przyjmować. To wszystko stać się nie może bez zewnętrznych spraw ciała, a każda sprawa ciała ma granicę na pewny punkt zmordowania i że tak rzekę nasycenia, przypuszcza lenistwo i wysilenie, a stąd nieuchronnie potrzebuje umiarkowania. Podobnie człowiek nie może inaczej pracować nad doskonałością swoją moralną, jak wykonując często dobre sprawy i w społeczności ludzkiej postępując sobie cnotliwie. Już zaś zewnętrzne postępowanie człowieka zależy w wielkiej części na sprawach ciała przez umysł kierowanych.

Łatwo więc Arystoteles mógł być wprowadzonym do błędu i twierdzenie wyrażające tylko ogólne prawidło umiarkowania poczytać za jedyną zasadę 
cnoty i moralności całej. Albo raczej ten sam błąd opiera się na prawdziwej zasadzie, iż w każdej dobrej sprawie potrzeb koniecznie czuwanie rozumu nad żądzami i zmyślnością i że w całym postępowaniu człowieka prawidło w nimi jest bardzo mądrym prawidłem. Atoli zasada Arystotelesowa staje się przez to niedostateczną, że nie tłumaczy istoty umiarkowania i że obowiązku do niej nie wyprowadza $z$ istotnych przymiotów człowieka, a nierównie jeszcze nie dostateczniejszą przez to, że prawidło w sobie zawarte w sposobie wcale niedoskonałym i tylko przez przenośnię wyraża. Nie jest że to albowiem przenośną nazywać cnotę środkiem pomiędzy dwiema ostatecznościami? Arystoteles porównywa cnotę z punktem, którego każdy linii albo z drogą, którą na wyznaczonej sobie powierzchni szukać powinien, a do znalezienia tego punktu albo tej drogi podaje prawidło z pierwszego pomiędzy dwoma końcami danej linii, tej zaś pomiędzy dwiema drogami dającymi się postrzegać na powierzchni szukać należy. Ten obraz ani jest zupełnie dokładnym, ani do zastosowania ku wyrażonej przez nie rzeczy dosyć łatwym. Atoli można powiedzieć, iż dwa są rodzaje zasad moralnych, że jedne wywodzą istotę cnoty z pierwiastkowych przymiotów człowieka, które od nas poznanymi być mogą to jest wyobrażenie obowiązku zasługi i powinności wyprowadzają z najprostszego wyobrażenia, do których w szczególnym rozbiorze każdej powinności koniecznie przychodzimy, drugie zaś jedynie są przeznaczonymi do praktycznego po drodze cnoty prowadzenia człowieka, który dążyć do doskonałości zamierzył. Zasada od Arystotelesa podana nie należy zapewnie do pierwszego. Zatem zapewne istotny i pierwiastkowy przymiot człowieka nie przymusza nas do przypuszczenia w każdej rzeczy środka i dwóch ostateczności i dostatecznego przenoszenia pierwszego nad ostatnie. Człowieka w rozbiorze wyobrażeń swoich moralnych natrafi zapewne na złote prawidło umiarkowania; ale to pomiędzy wspomnianymi wyobrażeniami ani jest najpierwszym ani najprostszym. Przeciwnie: w szczególnym zdarzeniach to prawidło może nierównie lepiej niż którakolwiek metafizyczna zasada pokazać mu o co się starać, a czego chronić powinien. Jeżeli zna, że w uniesieniach zmyślnej rozkoszy i w zapale gniewu przechodzi wszystkie granice i nie może słuchać ani cudzego, ani własnego rozumu, przekona się łatwo, że poskromienie zmyślności i spokojność umysłu w przykrych zdarzeniach są ściślejszymi dla niego powinnościami. Jeżeli poczuwa się być gnuśnym i leniwym z temperamentu, wtenczas do nieustannej czynności i odwagi pobudzać samego siebie będzie.

Arystoteles w rzeczy samej użył bardzo zręcznie zasady swojej w wielu przynajmniej cnotach do rzucania światła na ich przymioty niknące przed 
okiem zwyczajnym. Ogólnie mówiąc Arystoteles pomimo pozorów spekulacji w filozofii jego panujących, a przez tłumaczów mianowicie scholastyków, którzy wszędzie w jego dziełach subtelność przenosili nad pożytek jeszcze więcej onej nadanych, jest prawdziwym i bardziej praktycznym filozofem w tłumaczeniu szczególnych i pojedynczych przedmiotów niż w całym ogóle metafizyki swojej. Z drugiej strony, w postrzeżeniach swoich bardzo bywa często przez wyłożone pierwej ogólne zasady i wyobrażenia kierowanym. Jeżeli te same przez siebie nie objaśnianą przedmiotów w sposobie wystarczającym: nadają przynamniej pewny porządek objaśnieniu jego przez doświadczenie. Czyliż podobna okoliczność nie ma także miejsca w jednej z najsławniejszych zasadzie moralności Kanta? Czyliż twierdzenie, że ta sprawa jest rzetelnie dobrą, która wszystkim ludziom za powinność ścisłą prapisaną być może, zdatnym jest do służenia za podstawę całej moralności albo do wyprowadzenia z niego wszystkich powinności szczególnych? Mnie zaiste, wyznać to powinienem, zdawało się zawsze, ile razy zastosować go usiłowałem, iż przezeń pytanie, które powinno było rozwiązanym. Zostać zamieniało się na inne zagadnienia nieporównanie do rozwiązania trudniejsze. Człowiek szczerze kochający swoje powinności przychodzi do filozofa i pyta jak sobie ma postąpić w pewnym oznaczonym przypadku w pewnych okolicznościach, a filozof odpowiada mu, że powinien zapytać samego siebie, jaką by w tym przypadku ustawę dla całego narodu ludzkiego przyjął. Tamten chce tylko własnym swoim być prawodawcą i nie ufa jeszcze w tej mierze znajomościom swoim, a filozof mu nakazuje, że powinien być prawodawcą nie już jednego narodu, ale raczej całego rodu ludzkiego. Czyliż nie jeden członek zgromadzenia prawodawczego, umiejący bardzo roztropnie w prywatnym pożyciu postępować sobie, nie podaje nieraz bez rozumnych rad względem ustaw publicznych w podobnym jemu przypadku służyć mających. Tak nieporównanie trudniejszym jest tworzenie ustaw dla wielu osób niżeli tylko dla jednej, wynalezienie tego, co jest stosownym i przyzwoitym w wielu rozlicznych odmianach niżeli tego, co jednemu tylko służyć ma przypadkowi.

Zaiste, czyliż w podobnych badaniach droga poczynająca od szczególnych przedmiotów, a postępująca do ogółu całego, nie jest nierównie naturalniejszą i częściej używaną niżeli droga przeciwna? Gdyby mi na przykład przyszło dawać radę względem ustawy mającej za przedmiot małżeńskie rozwody albo powagę rodzicielską, wystawiłbym sobie naówczas żywo w pamięci wszystkie poróżnione między sobą małżeństwa, które oglądałem w mym życiu, uważałbym przyczyny obudzonej pomiędzy niemi niezgody, zastanawiałbym się nad osobistym każdego stadła położeniem, a stąd dopiero starałbym się albo 
wyliczyć wszystkie skutki rozwiedzionych lub w ciągłym podłym połączeniu prowadzonych małżeństw, albo rzetelne następności, które poznałem starałbym się samemu sobie wytłumaczyć. W każdym więc pojedynczym przypadku usiłowałbym rozwiązać najprzód zapytanie czy dobro tak całej społeczności jako i samych małżonków wyciągało rozwodu, czy nieprzerwanie i wiecznie ciągnionego małżeństwa. $Z$ podobieństwa albo niepodobieństwa tych szczególnych przypadków wniósłbym przyczyny w naturze człowieka małżeńskiego związku i wpływu społeczności domowej na dobro społeczeństwa cywilnego oparte i te rozróżniłbym od przyczyn pojedynczych tylko osobom i ich szczególnemu położeniu właściwych. Im więcej tych szczególnych przypadków zgłębiłbym i rozwiązał dla mnie samego, tym poczytałbym się za zdatniejszego do dania rady względem ogólnej ustawy o rozwodach. Podobnie przed ogólnym rozstrzygnięciem, jaki stopień rodzicielskiej władzy jest najprzyzwoitszym i najużyteczniejszym w społeczności, stawiłbym mnie samego w myśli za poradcę wielu szczególnym rodzicom jak sobie z dziećmi postępować i władzy rodzicielskiej używać nad niemi mają. Spytałbym się samego siebie, jakie prawa przyznać bym był powinienem temu albo owemu dobrze mi znajomemu ojcu nad rozwiązłemi dziećmi lub z nim że samym się kłócącemi, jakie skutki wydawałby w naszym wieku podług wszelkiego podobieństwa do prawdy surowość dawnego Rzymianina nad swymi dziećmi i jakie w rzeczy samej w niektórych przypadkach z niej wyniknęly. I w tym przypadku także ustawą albo wszystkich starałbym się wnieść i że tak rzekę złożyć w wielu szczególnych ustaw dla osób pojedynczych.

Lecz jeżeli owe maksymą Kanta niepoczytnie za zdatną do pokazania nam wszystkich szczególnych powinności naszych: widzę w niej zapał dzielny bardzo środek do praktycznego kierowania nami, w tych wszystkich pojedynczych przypadkach, gdzie samolubne namiętności tak łatwo obłąkiwać nad zwykły „co by stąd wyniknęło, gdyby wszystkie osoby w twoim położeniu i w twoich okolicznościach zostające to samo czyniły co ty sobie przywłaszczasz?” To często jest pożyteczną bardzo przestrogą dla człowieka przez pychę i miłość własną zasklepionego, który to zakłada samemu sobie za prawidło co najwięcej służyć by mogło za wyjęciu od prawidła, gdyby on nadzwyczajnym rozumem, charakterem lub położeniem nad cały naród ludzki górował.

Sądzę, iż te uwagi nad zasadą Arystotelesa podaną staną się przez to użyteczniejszemi, kiedy je porównam z celnemi zasadami przed nim i po nim od sławnych filozofów utworzonemi i kiedy zastanowię się nad postępem albo przynajmniej nad odmianami, którym nauka obyczajów co do pierwszych swoich zasad w przeciągu wieków uległa. Z pomiędzy dawnych utworzonych 
przed zaprowadzeniem chrześcijańskiej religii, która była źródłem nowego w cale sposobu uważania sposobności naszych, wyłożę obszerniej zasadę Platona i stoików: pierwszą, ponieważ Arystoteles miał ją przed sobą lub ani jej ze wszystkich stron nie obejrzał ani też przyzwoicie nie ocenił, z drugiej zaś strony, odkrył co w sobie zawierał słabego i wielokrotnie ją zbijał, drugą zaś, ponieważ żadna sekta filozofów nie uczyniła w sztuce obyczajów tak wielkich postępów jak stoicy, od których także pochodzi całe systematyczne dzieło, które w tej umiejętności ze wszystkich starożytnych dziś posiadamy. Ponieważ zaś po zaprowadzeniu chrześcijańskiej religii zasady filozoficznej moralności bardziej się rozmnożyły i na wiele różnych podzieliły gałęzi, będę się starał zebrać wszystkie do kilku głównych rodzajów, aby tym więcej zostało mi czasu do zastanowienia się nad zasadami, które powaga Kanta tak sławnemi w Niemczech zrobiła.

Obok Arystotelesowej zasady stawiam system Platona jego nauczyciela, od którego on systemj, a od Arystotelesa porzucone w wielu swoich częściach zbijane, a w całym ogóle nigdy przyzwoicie nieocenione. Platon więcej nierównie od Arystotelesa był zdatnym do zgłębiania ogólnych zasad moralności, chociaż pochodzący od niego scholastycy bardzo byli subtelnemi i w samych tylko zgłębiali się abstrakcjach, chociaż on sam w dziełach swoich nieraz pokazał się owym podobnym w ogóle jednako bardziej jest postrzegającym niż spekulującym filozofem. Platon był razem poetą i w rzeczy samej potrzeba nieco poetycznego ducha do zgłębiania tych przepaści ludzkiej natury, które samemu rozumowi zdają się nieprzeniknione. Do uchwycenia tego światła, które tam się ukrywa albo do wyjaśnienia ich własnym światłem niechaj bowiem mówią, co chcą, atoli pewną jest rzeczą, iż ci wszyscy, którzy w metafizyce do najwyższego podnieśli się szczytu i w szkołach najliczniejszych naśladowców znaleźli począwszy od Platona aż do Kanta nam współczesnego nie tylko byli głęboko myślącemi, za co jedynie ich poczytują, ale nadto okazali wiele dowcipu i pięknej imaginacji. Nie tylko owe jedne wyobrażenia wyprowadzali z drugich ale nadto wyobrażenia jedne $\mathrm{z}$ drugimi samowolnie łączyli, co jest zaiste dziełem poezji. To ja wnioskuję stąd, iż żaden $\mathrm{z}$ nich nie ważył się odłożywszy na stronę powszechnie przyjętych maksym, że np. nie godzi się nikogo zabijać, obierać z majątku albo obmawiać, stanowić własnych swych zasad, z których by wszystkie inne prawdziwe twierdzenia mógł wnosić. Wszyscy owe zwyczajne i od całego rodu ludzkiego 
za prawdziwe uznane maksymy poczytali za cel, ku któremu całą usilnością swoją dążyć i na którym wszystkie wnioski swoje kończyć mieli. Owe maksymy są na kształt zdarzeń i, a własne ich zasady na kształt fizycznych domysłów, które tym są doskonalszemi, im lepiej i dokładniej tłumaczą wszystkie fenomena. Ale takowe domysły nie tylko zapewne są dziełem wnioskującego rozumu, ale razem także samowolnie łączącej i układającej imaginacje. Atoli do Platona powracam.

Dzieło, w którym Platon najdokładniej rozwinął moralne swoje systema albo najlepiej zgłębił wartość i cenę przypisywane sprawom cnotliwym jest sławne dzieło jego o rzeczypospolitej. Wszyscy teraz wiedzą, że uwagi nad rządem najdoskonalszym, chociaż nadały inne całemu dziełu i znaczną część jego zapomną, nie były atoli głównym dzieła tego przedmiotem, ale były tylko przygotowaniem zaraz z początku całego dialogu utworzonego zapytania. „Dlaczego cnota jest czymś dobrym i skąd pochodzi ta wartość, która sprawiedliwym i cnotliwym sprawom powszechnie przyznawaną bywa, a której przeciwne im wcale nie mają? Czy cała ich cena zależy jedynie od zewnętrznych korzyści przypadkowej z niemi połączonych, a po rozgłoszeniu ich pomiędzy ludźmi, z któremi w stosunkach żyjemy powszechnie następujących? Albo czy znajduje się w samej sprawiedliwości i cnocie i czyli wtenczas nawet prawdziwie jest pożądaną, kiedy człowiek cnotliwym jest i sprawiedliwym w skrytości?"

Do rozwiązania tych pytań obiera Platon drogę bardziej poecie niż filozofowi przyzwoitą drogę porównywania. Przedmiot mający służyć ku porównaniu bardzo jest szczęśliwie wybranym, a wybór jego z wielkim dowcipem od Platona usprawiedliwionym. Atoli przed ukończeniem porównania nie mógł wcale uczniów swoich zapewnić czy przedmiot, z którym naturę ludzką porównywa i w którym wszystkie moralne przymioty człowieka niby w zwierciadle odmalowanymi być widzi, jest do niej tak zupełnie podobnym i tak z nią ściśle spowinowaconymi, iż wszystko, co w pierwszym postrzeże, służyć powinno bez żadnego wyłączenia drugiej. Umysł pojedynczego człowieka mówi Platon jest dla zwyczajnych oczu za drobnym i do postrzeżenia bardzo trudnym przedmiotem. Atoli w całej społeczności cywilnej znajdujemy też same przymioty władzy i działanie ludzkiej natury lecz w przyzwoitym już powiększeniu. I całe także cywilne społeczeństwo ludzi może być sprawiedliwym albo niesprawiedliwym, cnotliwym albo występnym, a stąd możemy w nim łatwo oglądać pierwszy początek sprawiedliwości i cnoty, widzieć jak ona między ludźmi zawiązuje się i utrzymuje, po wtóre możemy poznać jej skutki, to jest cały wpływ na dobro i prawdziwą ludzi szczęśliwość. Gdy- 
by więc to badanie szczęśliwie nam się udało, wielkie jest podobieństwo do prawdy, że łatwiej nierównie nam będzie poznać istotę sprawiedliwości i cnoty, ile ta jest przymiotem każdego szczególnego człowieka i oglądać stosunek zachodzący pomiędzy nią a osobistym szczęściem jego. Widzimy tu wprawdzie, że Platon zamierzając tym sposobem tłumaczyć cnoty naturę, musiał koniecznie wyrzec się wszelkiej apodyktycznej pewności i wszelkiego z samych ścisłych wniosków wynikającego przekonania. Nasz moralny zmysł, pospolity ludzki rozum muszą same potwierdzać rezultata $\mathrm{z}$ tego porównania wynikające, jeżeli te pokażą się albo z moralnymi uczuciami, albo z przeczuciami i teoriami zgodnymi. Uradujemy się zapewne nie pomału, jeżeli postępując tą drogą znajdziem na końcu jasne przepisy moralne i zachęcenie do cnoty wskroś serce przenikające. Lecz będzie to jedynie przypadkiem albo dziełem szczęścia lub geniuszu, kiedy droga takowa do pożądanego przyprowadzi nas kresu.

Kiedy Platon albo namiestnik jego Sokrates budzili swoją rzeczpospolitą, aby z nią razem cnotę i sprawiedliwość utworzyć, przy czym musi koniecznie zapuszczać się w mnóstwo przedmiotów obcych zupełnie głównemu zamiarowi swojemu, znajduje, że do każdego towarzystwa cywilnego trzy następujące pierwiastki są nieuchronnie potrzebnym; najprzód klasa osób rządzących, w której mądrość i rozum całego towarzystwa niby się zbiera wszystkie jego części równie ożywia i każdej właściwe przepisuje funkcje, to jest tworzy ustawy, wydaje powszechne rozporządzenia, które są jedynie dziełem mądrości i rozumu. Po wtóre: klasa broniąca, która pod dozorem i kierowaniem rządu wszystkich tak wewnętrznych, jako i zewnętrznych nieprzyjaciół odpędza. Powszechne ustawy przyprowadza do skutku, a zuchwałe i burzliwe namiętności szczególnych obywateli przymusza do słuchania powszechnego rozumu, to jest ustaw cywilnych. A w tej klasie najpotrzebniejszym przymiotem jest męstwo, to pomieszanie umysłowej cnoty z mocą ciała da, by ograniczenie jego męstwa, aby w wewnętrznym obcowaniu obrońców z obywatelami nie zamieniło się na zuchwalstwo; na koniec zupełne poświęcanie się rządowi i posłuszeństwo jego nakazom. Trzecim pierwiastkiem jest pracowita i używająca klasa, która upatrywać w potrzeby tak rządców i obrońców jak sama siebie powinna, a która dlatego nie tak mądrością i odwagą jak raczej porządkiem i umiarkowaniem, a mianowicie zupełnym ograniczaniem się własnym szczególnie zatrudnieniami obowiązana celować, przez co i posłuszeństwo jej ku zwierzchności i gotowość do wspomagania klasy broniącej najpewniej ubezpieczoną zostanie. 
Z tych trzech pierwiastków każda społeczność cywilna koniecznie składać się musi, jakże zaś one same być usposobionemi powinny, aby towarzystwo całe rzetelnie sprawiedliwym było, to jest aby i wewnętrznie pomiędzy obywatelami sprawiedliwość panowała i zewnętrznie ku obcym narodom spodziewać jej się można było?

Każda z nich musi być najprzód koniecznie tym, czy powinna. Dalej wszystkie pomiędzy sobą w najdoskonalszej znajdować się mają harmonii, aby $\mathrm{z}$ nich prawdziwa wynikała całość: ponieważ właśnie na połączeniu ścisłym istota i życie każdej społeczności zależy. Rząd przeto powinien być $\mathrm{w}$ rzeczy samej złożonym $\mathrm{z}$ najmądrzejszych i najcnotliwszych w całym narodzie mężów. Klasa uzbrojona powinna odwagę i szlachetną wzniosłość umysłu łączyć ze skromnością i rzetelnym sprzyjaniem obywatelom pracującym, a trzecia najliczniejsza pracowitych i w istocie potrzeby wszystkie inne upatrujących obywateli obowiązana posiadać ową pilność i umiarkowanie i spokojność umysłu, które są konieczne w ich położeniu potrzebnymi. Stąd zaś powstaje łatwe ich połączenie zupełne, jeżeli nadto każda ogranicza się własnymi tylko zatrudnieniami, nie występuje za okręg swego działania i nie miesza się w cudze prace. W tym przypadku rząd naturalnie będzie tylko znajomością swoją przeświecał wszystkim społeczności członkom, nie gnębiąc i nie uciskając ich po tyrańsku, rycerze wymagać będą zawsze swoim orężem mądrość rządzącą i bronić współobywateli pracowitych, a co ostatni spokojnie i z ochotą ulegać będą mądrym widokom zwierzchności, które za takie uznają, szanować i poważać rycerzy ani się ich bojąc, ani też nienawidząc, opatrywać ich we wszystko losowi ich wcale nie zazdroszcząc.

Teraz przyrównywa Platon społeczność cywilną z każdym pojedynczym człowiekiem, to jest z jego umysłem, a mianowicie z władzą chcenia, która jest środkiem i źródłem wszelkiej jego dzielności, znajduje w obydwóch zupełnie podobne pierwiastki i okazuje, że tak istota cnoty jako i przyczyna, dla której cnota godną jest pragnienia naszego zależy na wewnętrznym umysłu człowieka układzie, który jest do porządku i układu doskonały i szczęśliwej społeczności bardzo podobnym. Tu znowu widzieć wpływ, który mowa tak zwyczajna jako i filozoficzna tudzież od dawna uczynione różnice pomiędzy pojęciami i wyrazami na badania mędrców mieć zwykli. Porównanie nie byłoby tak łatwym dla Platona, a podobieństwo pomiędzy społecznością a szczególnym człowiekiem nie okazałoby się w całej zupełności, gdyby grecka filozofia tak jak dzisiejsza nie więcej rozróżniła w człowieku jak tylko rozumne i nierozumne pragnienia, a mowa wyrażała tylko dwa istotne umysłu ludzkiego pierwiastki, to jest rozum i zmyślność. Przeciwnie: tak w filozofii, 
jak w mowie greckiej jeszcze przez Platonem trzy takowe części powszechnie przyjętem były: logos, thymos, epithemia, których my nie możemy lepiej w ojczystym języku wyrazić jak wzorem uczynionego od scholastyków łacińskiego tłumaczenia, nazywając je rozumną, gniewliwą i pożądliwą częścią woli. Pierwszy i ostatni wyraz można poczytać za dokładne tłumaczenie odpowiadające greckim wyrazom, ale drugi bardzo niedokładnie wyraża znaczenie pierwiastkowe od Greków użytego słowa: thymos nie jest wcale gniewem, ten ostatni jest oznaczony w greckim języku innym wcale wyrazem, który z thymos żadnego nie ma stosunku. Gniew nawet podług filozofii greckiej jest namiętnością, a za tym zawsze nierozumnym; i jako każda namiętność szybko przemijającym; przeciwnie thymos jest czynem trwałym i zawsze obecnym w człowieku; jest to pierwiastkowy popęd w człowieku, który wprawdzie czasem rozumnym być może, atoli często obudza się bez żadnego wpływu rozumu i spod władz jego usuwa.

Wątpić nie można, iż szczególniejsza wartość, którą odwadze i męstwu przypisywali Grecy, wtenczas nawet, kiedy te przymioty nie gniewały się na zasadzie rozumu i tylko machinalnie działały, zniewoliła także filozofów do przenoszenia owych popędów, które człowieka unoszą do dania oporu nieprzyjaciołom, to jest tym, którzy go niesprawiedliwie pokrzywdzili nad owe, które skłaniając go do szukania rozkoszy i do unikania boleści czynią go tym samym miękkim i osłabiają jego naturę, kiedy tamte wszystkie władze jego umysłu podnoszą i wzmacniają.

Atoli początek tej filozofii Greków niech będzie jaki chce, to jednak niezaprzeczoną jest rzeczą, że ono owe popędy, które samą przyjemność za cel mają i do zmyślnej unoszą nas rozkoszy od tych, którzy stronią od wszelkiej nieprzyjemności i oburzają nas przeciwko złemu i ku wszystkim prawom niesprawiedliwości nierównie więcej od nas rozróżniali, że tym ostatnim nierównie większą cenę niż pierwszym przypisywali, i że one między tymi obiema niby złożone $\mathrm{z}$ obu w środku umieszczali. Aby usprawiedliwić to pierwszeństwo, które wstrętowi ku wszelkiej nieprzyjemności nad skłonnością ku uciechom zmyślnym nadawali, umieszczali w wyobrażeniu pierwszego cechę, która wcale nie znajduje się w samej, o której mowa rzeczy, to jest $\mathrm{w}$ wspomnianym dopiero wstręcie. Poglądali na niego jako na niechęć ku wszelkiemu pokrzywdzeniu od innych nam zadanemu, a za tym jakie [??]na niechęć ku wszelkiej niesprawiedliwości widzieli przeto w nim wstręt prawdziwie moralny. Ale to machinalna odwaga, która nas bronić od wszystkich pokrzywdzicieli powinna dla tego samego, że jest ślepą i bezrozumną, równie zajmuje się przeciw rzetelnym jak i urażonym nieprzyjacielem, owszem 
bardzo często ku dobroczyńcom rzetelnym. Tym czasem Platon znalazłszy od dawna zaprowadzoną różnicę pomiędzy logos, thymos, epithemia, to jest pomiędzy praktycznym rozumem, pomiędzy gniewliwemi, czyli jak dokładniej można by wytłumaczyć mściwemu i każącemu, tudzież pomiędzy skłaniającymi nas do rozkoszy uniesieniami woli łatwo mógł widzieć w sercu człowieka wszystkie trzy pierwiastki w społeczności cywilnej i zastosować do niego wszystko co do dobrego urządzenia tej ostatniej poznał być nieuchronnie potrzebnym. Rozum tym jest oczywiście w człowieku, czym klasa rządców w społeczności władzą najwyższą i panującą nad nim całym przeznaczoną przez znajomości swoje do wydawania ustaw i rozrządzania, a dla tych równie jak dla wolności i niezawisłości swojej od wpływu ciała nad wszystkie inne jego władzę wzniesioną. Thymos niemniej był podobnym do klasy obrońców jako mający bronić przeciwko napaści człowieka i przyprowadzać do skutku wszystkie układy rozumu, ile ten do wykonania owych pomocy ciała potrzebuje. Epithemia, to jest chęć ku zmyślnym uciechom, a tym samym ku honorom i dostatkom, które są do nich środkami, równie widocznie wystawiała zarabiająca klasa w społeczności, która zajmuje się jedynie przedmiotami korzyści i interesu i ku nim dąży równie ślepo i równie bez żadnego oburzenia się na publiczne dobro w społeczeństwa, jak chciwość dostatków i honorów szuka celu swojego bez żadnego względu na najwyższe dobro i przeznaczenie człowieka.

Jako więc społeczność cywilna jest obrazem wewnętrznego człowieka, tak społeczność doskonale urządzona będzie także obrazem doskonałego człowieka. Przez też same prawidła i przez też same urządzenia człowiek staje się cnotliwym i szczęśliwym, które w społeczności cywilnej obyczajność i pomyślność wydają. Już zaś podług Platona doskonała społeczność na dwóch szczególniej opiera się zasadach: najprzód, aby wszystkie jej członki, a mianowicie trzy główne pierwiastki, takiemu były w rzeczy samej, jakimi być powinny i to wszystko czyniły, do czynienia czego są przeznaczone, po wtóre, aby pomiędzy sobą najściślejszą zgodę i harmonię zachowały. Ale ten drugi warunek jest oczywiście skutkiem i wnioskiem pierwszego: mianowicie, jeżeli to zachowanym zostanie, co tak często i tak usilnie Platon zachęca, to jest jeżeli każdy członek będzie się jedynie zajmował przepisanym sobie zatrudnieniem, nie wdając się natrętnie w zatrudnienia drugich. Nigdy albowiem w tej społeczności nie powstanie kłótnia, gdzie każdy spokojnie przestając na tym, co drugi w okręgu swoim czyni, stara się wykonywać dokładnie swe własne przeznaczenie. Kiedy już w człowieku rozum w rzeczy samej pełny jest wiadomości i wszystkimi władzami jego kieruje, kiedy machinalna od- 
waga wzmocniona przez siłę i przyzwoite ćwiczenie ciała zawsze i jedynie na głos rozumu walczy przeciw nieprzyjaciołom sprawiedliwości z poświęceniem nawet życia własnego, kiedy wewnętrznych nieprzyjaciół cnoty, to jest zmyślne i nieumiarkowane skłonności przyzwoicie trzyma na wodzach, jeżeli na koniec zawsze czynny popęd, który nas ku rozkoszy unosi, a który się rychło już to na chciwość dostatków, już to na żądzę honorów sam przez siebie zamienia, zostanie zamkniętym $\mathrm{w}$ granicach od rozumu sobie przepisanych i kiedy przez tę samą ograniczoną, atoli jednak zupełną dzielność wszystkich władz i chęci najdoskonalsza między innymi powstanie harmonia, człowiek takowy czyliż cnotliwym i szczęśliwym nie będzie? Będzie cnotliwym, bo jako rozumny i wszędzie powodowany rozumem posiada zapewne roztropność, posiada umiarkowanie, ponieważ wszystkie jego żądze zostają pod panowaniem rozumu; jest odważny, ponieważ posiada machinalne męstwo, które zawsze kierowane rozumem walczy jedynie przeciw nieprzyjaciołom sprawiedliwości i widokiem dobra powszechnego statecznie jest ożywionym. Kto zaś te trzy cnoty posiada, temu zbywać nie może na czwartej, która niczym innym nie jest, tylko uzupełnieniem i rezultatem trzech pierwszych, kiedy te połączone ze sobą w zewnętrznym świecie i w towarzystwie ludzkim działają. Tenże sam człowiek jest jeszcze prócz tego szczęśliwym, ponieważ stan jego duszy jest zupełnie podobnym do stanu ciała doskonale mającego zdrowie. Każda część i każda władza duchowej jego natury tak jest zupełnie urządzoną, jak być urządzoną powinna i funkcje swoje jak najdoskonalej odbywa. A przez zgodność i harmonię różnych skłonności i popędów jest jeszcze zabezpieczony drugi warunek nieuchronnie do prawdziwego uszczęśliwienia potrzebny, to jest wewnętrzna spokojność umysłu i upodobania w samym sobie. Stąd już sama przez siebie nieoceniona prawda wynika, że cnota jest godna szacunku, a sprawiedliwość powinnością nie tylko dla tego, iż w towarzyskim pożyciu bardzo wiele człowiekowi ogólnie przynajmniej mówiąc zwykła przynosić korzyści, ale że nawet ukryta w sercu człowieka i ani przez szacunek ludzki, ani przez inne pożytki nienagrodzone wewnętrzne uszczęśliwienie jego stanowi.

Tak wyłożona ode mnie platonicznej moralności zasada tak w sobie samej, jako i ze względu na prosty ludzki rozum, któremu zupełnie czyni za dosyć, warto być przeniesiona nad zasadę przez Arystotelesa podaną. Ale ze względu na dowód swej prawdziwości i rzeczywistego wystarczania tudzież ze względu na sposób, którym od Platona wyprowadzoną i zastosowaną została, równym jak tamta niedostatecznością ulega. Zasada Arystotelesowa zawierała w sobie przenośnię, zasada platońska jest na alegorii zbudowana. 
A wszystkie porównania, jakkolwiek szczęśliwie dobranymi będą obrazy, jakkolwiek zastosowania zgodnymi być mogą z rzeczywistością, służą jedynie do lepszego wyjaśnienia rzeczy, lecz nigdy nie okazują, że ona tak się ma sama $\mathrm{w}$ sobie, a nie inaczej. Do wynalezienia przeto prawdziwie pierwszej moralności zasady należało koniecznie zgłębić ludzką postawę w samej sobie i bez żadnego względu na jakąkolwiek rzecz inną, chociaż z nią najbardziej spowinowaconą. I czymże jest społeczność, której porównanie z pojedynczym człowiekiem miało nam dać poznać tego ostatniego cnotę moralną? Niczym innym, jak tylko zebraniem pojedynczych osób, większą albo mniejszą liczbę indywiduów wzajemnie ze sobą połączonych. Czymże jest przeto społeczność szczęśliwa, jeżeli nie społecznością, w której wszystkie stanowiące ją członki są szczęśliwymi? A czymże innym jest społeczność sprawiedliwa, jeżeli nie społecznością, której wszystkie członki sprawiedliwymi są i cnotliwymi, a w której mianowicie klasa rządząca jako trzymająca miejsce wszystkich innych i obwieszczająca ich wolę przymuszona jest przez pospolitą obywatelów cnotę do okazywania statecznej sprawiedliwości, tak względem ich samych jako i względem obcych narodów. Można więc sądzić o sprawiedliwości i cnocie społeczności jakowej, jeżeli nie poznamy pierwej, co sprawiedliwymi i cnotliwymi czyni pojedyncze osoby. Nierównie przeto naturalniejszą byłoby rzeczą z uwag nad cnotliwym i doskonałym pojedynczym człowiekiem wnieść dopiero uwagi nad doskonałą i przyzwoicie urządzoną społecznością niż udawać się jak uczynił Platon drogą przeciwną. W rzeczy samej albo nie dowiedzie Platon, że jego dobrze urządzona społeczność jest w rzeczy samej cnotliwą i sprawiedliwą, albo dowód jego będzie należał do tego rodzaju dowodów, który się u łacinników peticii principii nazywa. Uważyłem już pierwej, że tylko przypadkowa, a przynajmniej niczym niedowiedziona zgodność podziału władzy chcenia u człowieka z podziałem społeczności cywilnej na istotne swe części dało powód do szczęśliwego porównania natury człowieka z społecznością i przywiodło do oglądania pozornego jakiegoś podobieństwa między tymi dwiema rzeczami.

Do tego jeszcze przydaję, że aby jaka zasada moralności była prawdziwie pierwsza i doskonała, zupełnie trzeba koniecznie, ażeby najprzód okazywała dlaczego cnota jest dobrą, a powinność rzetelnie obowiązującą, po wtóre ażeby wszystkie szczególne powinności mogły być nie jedne wniesionemi. Ze względu na punkt pierwszy zasada platoniczna ma rzeczywistą zaletę. Nierównie widoczniejszą jest rzeczą, iż doskonały stan tych pierwiastków, które istotnie umysł ludzki składają we względzie, mianowicie na czynność człowieka, przez którą właściwie człowiek okazuje się człowiekiem połączo- 
ny zupełną między sobą tychże pierwiastków harmonią stanowi właściwie szczęśliwość i najwyższe przeznaczenie człowieka niż że szczęśliwość i przeznaczenie jego na tym jedynie zależą, aby we wszystkich sprawach swoich pomiędzy dwiema ostatecznościami doskonały środek zachował. Ze względu na punkt drugi zasada platoniczna nie wyrównywa wcale Arystotelesowi. Trudno zapewne byłoby Platonowi wszystkie ustawy prawa przyrodzonego i całą w zupełności etykę z zasady swojej wyprowadzić. Przeciwnie Arystotelesowi udało się bardzo dobrze wszystkie cnoty i powinności człowieka niektóre tylko uczyniwszy wyjęcia wnieść i wyprowadzić z umiarkowania ponieważ w rzeczy samej jak powiedziało się wyżej w istocie zewsząd ograniczonej każda pojedyncza dzielność powinna być także ograniczoną, jeżeli być nie ma szkodliwą i bezrozumną. Atoli odłożywszy na stronę niedostatek prawdziwie gruntownego dowodu, tudzież owe własności, które na zasadę platoniczną spływają stąd, iż ona podobno nie tak na rzetelności samej, jak raczej opiera się na samowolnie od Greków pomiędzy władzami człowieka uczynionej różnicy, wyznać jednak potrzeba, iż nad wszystkie inne zasady, które od początku pomiędzy ludźmi filozofii utworzono ona sama warta być przeniesiona. Nie można lepszej i mocniejszej podstawy cnocie człowieka założyć jak wystawiając one za doskonały stan za, iż tak rzekę jego umysłu; nie można silniej przekonać człowieka o tym, że cnota z natury swojej jest szczęśliwością i najwyższym dobrem dla niego jak kiedy mu powiemy, że dla jago umysłu tym jest właściwie cnota, czym jest zupełne zdrowie dla jego ciała. I w rzeczy samej, ponieważ cnota niczym innym nie jest tylko pewnym usposobieniem ludzkiej natury i jedynie wytłumaczoną być może niepodobna inaczej utworzyć sobie o niej wyobrażenia tylko albo znalazłszy człowieka, który by co do owej części swojej natury, która go właściwie czyni człowiekiem zupełnej doszedł dojrzałości albo przynajmniej obraz tak dojrzałego i doskonałego człowieka dobrowolnie, tworząc i składając w naszym umyśle.

Prawda, że tu zawsze trudność zachodzi czy takowa cnota jest wolna. Cała ta wewnętrzna doskonałość, która podług naszego założenia stanowi cnoty istotę albo przynajmniej koniecznie do niej należy, niezależny jedynie od jego woli i od jego spraw dobrowolnych nie mniej jak przyzwoity skład członków jego ciała i porządne krążenie płynów nie jest skutkiem upodobania jego. Ale ta trudność jest wszystkim moralnym systematom wspólną, a pytanie dawno już przez Greków utworzone, lecz zawsze niemal po sofistycku od nich rozwiązywane czy cnoty może się człowieka sztuką i własnym usiłowaniem nauczyć albo czy ona natury i nieba jest darem, zawsze będzie wielkie trudności chcącemu go zgłębić stawiało. W samej rzeczy cnota ludzka jest mieszaniną 
z natury i wolności z wrodzonych każdemu przymiotów i dobrowolnym ćwiczeniem nabytych usposobień. Na cóż by się przydało zaprzeczać to w teorii to bardzo głośno doświadczenie opowiada. Może ten nabyć roztropność kto z samej natury słabego jest umysłu? A człowiek prawdziwie mądry posiada powszechnie znakomite talenta. Sprawiedliwość ostać się długo bez życzliwości i dobroci nie może, a życzliwość i dobroć od czułości serca zależą. Do jakiego stopnia odwaga zależy od wewnętrznego czucia czerstwości i mocy ciała od pewnego poruszenia płynów krążących i pewnej gorącości temperamentu uznanych zostało od wszystkich wielkich mężów którzy posiadali tę cnotę, a jeszcze wyraźniej od Greków, którzy w języku swoim mają osobną cnotę męstwa, a osobno zmyślny popęd, którego my inaczej wytłumaczyć nie możemy tylko podobnie przez męstwo albo odwagę.

Ponieważ więc mało obrażać mnie może ów niedostatek platonicznej zasady, mocą którego rozróżnić przyzwoicie nie można co w tej czerstwości duszy lub w tej doskonałej harmonii albo w tym doskonałym usposobieniu umysłu, na którym cnota zależy pochodzi właściwie od wolności człowieka, a co jest darem natury albo szczęścia, ponieważ ta niemożność nie tak wypływa $z$ platonicznego systematu jak raczej z przyrodzonych rozumu ludzkiego granic, wyznaję przeto, iż systema Platona takie przynajmniej, jakie ode mnie pojętym i wyłożonym być mogło łączy się bardzo ściśle z własnym moim systematem. Człowiek nieskaleczony na rozumie i sercu, a w którym obydwie z władz zupełnie są zdrowymi i dojrzałymi we wszystkich sprawach swoich koniecznie cnotliwym być musi, z jakiejkolwiek wreszcie przyczyny ta wewnętrzna doskonałość rozumu i serca wynika. Jego sprawy mogą być zawsze poczytanymi za wolne chociażby usposobienie umysłu, z którego właściwie pochodzą nie było wolnym rzetelnie. Któreż albowiem sprawy ludzkie zasługiwałyby na imię prawdziwie moralnych, gdyby wtenczas dopiero mogły mu być właściwie jako istocie wolnej przypisanymi, kiedy całe wewnętrzne usposobienie jego, od którego wielkiej części zależą miało być koniecznie dziełem jego własnej woli bez żadnego wpływu przyczyn koniecznie działających. Już zaś kiedy człowiek do doskonale usposobienie umysłu będące jego podziałem wraz z jego wpływem na wszystkie swoje sprawy z prawdziwym uczuciem w sobie uznaje. Uznaje także, że nieustanne staranie się o utrzymanie i pomnożenie tej wewnętrznej doskonałości umysłu jest rzetelną cnotą, a ponieważ to utrzymanie i pomnożenie stać się inaczej nie może tylko przez ciągłe powtarzanie spraw wspomnianemu charakterowi doskonałości zupełnie odpowiadających jasną jest rzeczą, iż wspomniane sprawy za ścisłą swoją powinność koniecznie poczytywać musi. 
Cnota więc podług tego systematu jest powinnością albo najprzód ile sobie człowiek wyższą jakąś istotę wyobraża sposobną do dawania mu ustaw i oraz stosownie, a stosownie do poznania jego natury i wszystkich odmian, przez które ta przechodziła i prawdziwego stanu, który przyjęła przepisującą mu prawidła postępowanie, które wiernie zachować byłoby powinnością jego, albo ile człowiek w samym sobie dwie odmienne rozpoznaje istoty, istotę wyższą rozumniejszą do rządzenia i rozkazywania przeznaczoną, jaką w rzeczy samej jest rozum tudzież inną niższą mniej rozumną i która ulegać pierwszej powinna, jaką w ogóle jest zmyślność i wszystkie do niej odnoszące się żądze. W tym więc przypadku to, co dla całego człowieka jest cnotą, to jest doskonałością i uszczęśliwieniem względem wyższej jego części będzie rozkazem, a względem niższej przymusem i posłuszeństwem [ciąg dalszy zostanie opublikowany w następnych numerach].

Tekst opracowała Marta Agata Chojnacka 